\title{
Perencanaan dan Pengendalian Aktiva Tetap
}

\author{
Lidya Martha \\ Dosen pada STIE"KBP" Padang
}

\begin{abstract}
Abstrak
Aktiva tetap yang dibahas merupakan aktiva tetap berwujud yang digunakan oleh perusahaan untuk kegiatan usahanya, tidak dimaksudkan untuk diperjualbelikan dan mempunyai masa manfaat atau kegunaan lebih dari satu tahun serta mempunyai nilai material. Prosedur pengelolaan aktiva tetap dimulai dari tahap perencanaan pengadaan aktiva tetap dan diakhiri pada kegiatan pencatatan, yaitu meliputi prosedur pengadaan barang inventaris, prosedur reparasi dan pemeliharaan, prosedur penghentian/penghapusan aktiva tetap, prosedur penyusutan, prosedur revaluasi. Prosedur pengelolaan aktiva tetap ini dilakukan karena aktiva tetap mempunyai karakteristik yang berlainan dengan aktiva lancar. Jika aktiva lancar dikendalikan pada saat konsumsinya, sedangkan pengendalian aktiva tetap dilaksanakan pada saat perencanaan perolehan atau pengadaan aktiva tetap tersebut.

Kata kunci : aktiva tetap
\end{abstract}

\section{Pendahuluan}

Perusahaan merupakan organisasi modern yang mempunyai kegiatan tertentu untuk mencapai tujuan yang dibebankan kepadanya. Biasanya disamping mencari laba tujuan perusahaan juga mencakup pertumbuhan yang terus menerus, kelangsungan hidup, dan kesan positif dimata publik. Untuk mencapai tujuan tersebut tentunya perusahaan membutuhkan aktiva tetap dan menguasai faktorfaktor produksi. Proses ini sering juga disebut dengan proses produksi. Untuk menghasilkan produk ini maka peran aktiva tetap sangat besar, seperti bangunan sebagai tempat pabrik dan kantor, mesin dan peralatan sebagai alat untuk berproduksi, kendaraan pengangkut sebagai alat untuk mengangkut investasi kantor.

Informasi keuangan disajikan dalam bentuk laporan keuangan. Laporan keuangan utama yang dihasilkan dari proses akuntansi adalah neraca dan laporan rugi laba. Salah satu pos dalam neraca adalah aktiva tetap. Aktiva tetap dalam neraca yang dibahas merupakan aktiva tetap berwujud yang digunakan oleh perusahaan untuk kegiatan usahanya, tidak dimaksudkan untuk diperjualbelikan dan mempunyai masa manfaat atau kegunaan lebih dari satu tahun serta mempunyai nilai material.

Aktiva tetap dalam operasional perusahaan merupakan suatu aset yang sangat besar nilainya serta sangat berpengaruh terhadap laporan keuangan. Untuk mempertahankan aktiva tetap yang dimiliki dan digunakan dalam proses operasi, perusahaan memerlukan perencanaan dan pengendalian yang tujuannya agar dapat memenuhi kebutuhan perusahaan, termasuk untuk meningkatkan kapasitas 
produksi ataupun mutu produksinya. Pengeluaran tersebut akan dipisahkan apakah pengeluaran tersebut tergolong pengeluaran modal (capital expenditure) atau pengeluaran pendapatan (revenue expenditure).

Perencanaan aktiva tetap diperlukan dengan tujuan menetapkan tingkat pembelian yang mungkin diperoleh atas investasi aktiva tetap yang direncanakan dan menetapkan bahwa seluruh pengeluaran untuk barang modal yang direncanakan berada dalam batas-batas kemampuan keuangan perusahaan. Dalam perusahaan selain perlunya perencanaan dalam melaksanakan operasional perusahaan juga perlu adanya pengendalian agar perencanaan yang telah ditetapkan berjalan dengan baik sesuai dengan yang diharapkan, tanpa pengendalian yang baik maka rencana yang telah disusun itu tidak akan mungkin dapat dilaksanakan sebagaimana mestinya. Pengendalian akan efektif bila manajer mampu mendapatkan informasi akurat dan tepat pada waktunya.

Mengingat pentingnya keberadaan aktiva tetap dalam kegiatan operasional perusahaan, maka diperlukan sebuah sistem akuntansi aktiva tetap. Sistem akuntansi aktiva tetap direncanakan untuk menghasilkan informasi yang berguna bagi pihak luar maupun dalam perusahaan. Dalam pengendalian aktiva tetap ada beberapa hal yang harus diperhatikan baik dalam perawatan dan penilaian kembali aktiva tetap tersebut, serta dalam membeli dan kapan menghapusnya. Sehingga terhindar dari keruginan yang dibebankan oleh pembelian atau penghapusan suatu aktiva.

\section{Permasalahan}

Dana yang tertanam dalam aktiva tetap sebenarnya sama dengan dana yang tertanam dalam aktiva lancar. Perusahaan berinvestasi dalam aktiva lancar adalah dengan harapan bahwa perusahaan akan memperoleh kembali dana yang telah ditanamkan tersebut. Perusahaan berinvestasi dalam aktiva tetap adalah juga untuk memperoleh kembali dana yang telah ditanamkan tersebut. Perbedaan diantara keduanya adalah, investasi pada aktiva lancar diharapkan akan dapat diterima kembali dalam waktu dekat (paling lama satu tahun). Sedangkan investasi dalam aktiva tetap, dana yang tertanam akan diterima kembali dalam jangka waktu yang lama. Oleh karena itulah penulis tertarik untuk menulis tentang "Perencanaan dan Pengendalian Aktiva Tetap".

\section{Pembahasan}

\subsection{Perencanaan}

Tujuan perusahaan didirikan adalah mencari keuntungan sesuai dengan yang direncanakan, upaya mencapai tujuan tersebut antara lain diperlukan kegiatan yang mendukung kelancaran operasi perusahaan. Kelancaran operasi perusahaan yang dapat dilaksanakan dengan baik, bila sebelumnya dilakukan perencanaan yang baik bila dalam proses penyusunan didasarkan kepada berbagai factor kualitatif maupun kuantitatif.

Dalam suatu perusahaan perencanaan sangat dibutuhkan terutama untuk memberikan arah dan menjelaskan tujuan dari kegiatan perusahaan tersebut. Program usaha untuk masa yang akan datang harus direncanakan dengan memperhatikan kondisi - kondisi yang diharapkan dan diestimasikan kondisi 
ekonomi yang dinamis mudah sekali terpengaruh oleh kondisi politik, sosial ekonomi dan kondisi lainnya. Untuk lebih jelasnya berikut dikutip dari pendapat para ahli tentang perencanaan.

Menurut Malayu SP. Hasibuan $(2001 ; 91)$ pengertian perencanaan adalah fungsi dasar (fundamental) manajemen, karena organizing, steffing, directing dan controlling pun harus dulu direncanakan. Perencanaan merupakan salah satu fungsi utama dari seorang manajer. Perencanaan berantai suatu proses pemikiran dan penentuan terlebih dahulu apa yang akan dilakukan dalam rangka mencapai tujuan yang telah ditetapkan.

Perencanaan menurut Hansen dan Mowen (2000;354) dalam bukunya “Akuntansi Manajemen”, yang diterjemahkan oleh Ancella. A. Hermawan mendefinisikan perencanaan adalah pandangan kedepan untuk melihat tindakan apa yang seharusnya dilakukan agar dapat mewujudkan tujuan-tujuan tertentu.

Menurut M. Nafarin $(2004 ; 1)$ pengertian perencanaan (planning) merupakan tindakan yang dibuat berdasarkan fakta dan asumsi mengenai gambaran kegiatan yang dilakukan pada waktu yang akan datang dalam mencapai tujuan yang diinginkan.

Dari defenisi diatas dapat diambil kesimpulan bahwa perencanaan merupakan perumusan tujuan yang hendak dicapai serta cara - cara dan alat - alat yang dipakai untuk mencapainya. Jadi pada dasarnya perencanaan itu berisikan penetapan apa yang akan dilakukan, kapan akan dilakukan, dan bagaimana melakukannya.

Di dalam perencanaan tersebut ditentukan pula kebijaksanaan dan rencana kerja. Baik mengenai waktu maupun cara melaksanakan pekerjaan. Agar dapat terlaksana dengan baik maka perencanaan harus ditunjang dengan keputusan - keputusan yang mengatur pelaksanaan dari rencana tersebut.

Berhasilnya tidaknya suatu perusahaannya pada umumnya ditandai dengan kemampuan pemimpin dalam melihat kemungkinan dan kesempatan untuk masa yang akan datang, karena merupakan tugas pimpinan untuk merencanakan masa depan perusahaan agar kesempatan masa depan perusahaan yang telah direncanakan sebelumnya dapat tercapai sesuai dengan tujuan dari perusahaan.

Pada umumnya perencanaan perusahaan dapat dibagi kedalam dua jenis yaitu :

a. Perencanaan jangka panjang

Perencanaan jangka panjang disusun untuk jangka waktu 5 sampai 20 tahun atau lebih. Perencanaan ini juga disebut sebagai perencanaan strategis,karena menyangkut tindakan dan tingkat keputusan yang strategis untuk mencapai tujuan jangka panjang perusahaan. Titik berat dalam perencanaan strategis adalah penentuan tujuan perusahaan dan aktivitas serta strategi yang diperlukan untuk mencapai tujuan tersebut.

b. Perencanaan jangka pendek

Perencanaan jangka pendek yang juga disebut perencanaan dioperasional atau tahunan, yang menitik beratkan pada segi keuangan semua sarana dan norma prestasi dicantumkan dalam bentuk hasil keuangan.

3.2. Pengendalian 
Rencana yang telah diambil disusun dan dilaksanakan harus disertai dengan pengendalian yang baik agar tujuan yang telah ditetapkan dapat tercapai. Tanpa pengendalian yang baik maka rencana yang telah disusun itu tidak akan mungkin dapat dilaksanakan sebagaimana yang diharapkan.

Pengendalian merupakan usaha menyesuaikan pelaksanaan sesuatu rencana dengan rencana yang telah ditetapkan semula, sehingga apa yang hendak disetujui oleh perusahaan itu dapat tercapai. Dengan pengendalian yang mungkin terjadi dapat ditekan dan kemungkinan timbulnya kerugian terjadi dapat dihilangkan atau setidaknya diperkecil. Pengendalian yang baik dapat menghasilkan efisiensi dalam bentuk penghematan - penghematan. Dengan demikian untuk terlaksananya pengendalian menghendaki adanya tujuan dan rencana. Semakin sempurna pula pengendalian yang dapat dilakukan/

Untuk lebih jelasnya berikut ini dikutipkan pendapat beberapa ahli tentang pengendalian. Menurut Welsch, Hilton, Gordon (2000:13) dalam bukunya "Anggaran Perencanaan dan Pengendalian Laba". Yang diterjemahkan oleh Purwatiningsih dan Maudy Warouw, menyatakan bahwa pengendalian adalah suatu proses untuk menjamin terciptanya kinerja yang efisien yang memungkinkan tercapainya tujuan perusahaan pada dasarnya, pengendalian mengukur kinerja dengan membandingkan hasil aktual dengan hasil yang direncanakan dan mengukur penyimpangan yang terjadi. Apabila terjadi penyimpangan harus dilihat apa penyebab dan tindakan perbaikan yang perlu diambil.

Sedangkan menurut R.A Supriyono (2001:6) pengendalian merupakan proses yang digunakan untuk menjamin agar para pelaksanaan bekerja dengan efektif dan efesien dalam rangka mencapai tujuan bagian organisasi yang telah ditentukan terlebih dahulu.

Menurut Malayu SP. Hasibuan (2001;102), menyatakan proses pengendalian melalui beberapa tahap yaitu :

1. Menentukan standar - standar yang akan digunakan dasar pengendalian.

2. Mengukur pelaksanaan atau hasil yang telah dicapai.

3. Membandingkan pelaksanaan atau hasil dengan standar dan pelaksanaan dengan tujuan sesuai dengan rencana.

Apabila suatu proyek telah disetujui, kita perlu mempunyai cara - cara pengendalian yang wajar untuk memastikan bahwa ikatan dan pengeluaran dilakukan dalam batas - batas yang telah disetujui dan bahwa pengeluaran telah dipertanggungjawabkan sebagaimana mestinya.

Prosedur pengendalian Menurut Welsch, Hilton, Gordon (2000:14) yang diterjemahkan oleh Purwatiningsih dan Maudy Warouw dalam bukunya "Anggaran, Perencanaan dan Pengendalian Laba", adalah sebagai berikut:

1. Membandingkan kinerja aktual untuk periode yang bersangkutan dengan tujuan dan standar yang telah ditetapkan sebelumnya.

2. Menyiapkan laporan kinerja yang berisi hasil aktual. Hasil yang direncanakan dan selisih antara keduanya.

3. Menganalisis penyimpangan antara hasil aktual dengan hasil yang direncanakan dan mencari sebab-sebab dari penyimpangan tersebut. 
4. Mencari dan mengembangkan tindakan alternatif untuk mengatasi masalah dan belajar dari pengalaman pihak lain yang telah sukses disuatu bidang tertentu.

5. Memilih tindakan koreksi dari kumpulan alternatif yang ada dan menerapkan tindakan tersebut.

6. Tindakan lanjut atas pengendalian untuk menilai efektifitas dari tindakan koreksi yang diterapkan dan dilanjutkan dengan umpan maju untuk membuat perencanaan periode berikutnya.

Sebagai alat bantu manajemen pengendalian perusahaan mempunyai beberapa jenis pengendalian. Menurut Welsch, Hilton, Gordon yang diterjemahkan oleh Purwatiningsih dan Maudy Warouw dalam bukunya "Anggaran, Perencanaan dan Pengendalian Laba", jenis-jenis pengendalian dibagi menjadi tiga jenis antara lain sebagai berikut :

a. Feed forward control (stering control)

Pengendalian ini dirancang untuk mengatasi atau penyimpangan dari tujuan dan kemungkinan koreksi dibuat sebelum suatu tahap kegiatan tertentu dilaksanakan. Jadi pendekatan pengendalian ini lebih aktif dan agresif mendeteksi masalah terjadi. Pengendalian akan efektif bila manajer mampu mendapatkan informasi akurat dan tepat pada waktunya.

b. Concarent control (yes or no control)

Tipe pengendalian ini merupakan proses dimana aspek tertentu dari suatu persediaan harus disetujui terlebih dahulu atau syarat tertentu harus dipenuhi sebelum dilanjutkan tanpa adanya kondisi yang telah ditentukan, maka bagian yang melaksanakan harus meminta izin dahulu pada manajer yang lebih tinggi dan mereka yakin bahwa tindakan yang dilakukan adalah benar hal ini akan mengurangi intentif dalam bertindak.

c. Feedback control (post action control)

Pengendalian feedback ini mengukur hasil - hasil dari suatu kegiatan yang telah dilakukan. Sebab - sebab penyimpangan dari rencana dan penemuan - penemuan diharapkan untuk kegiatan serupa dimasa yang akan dating, pengendalian ini bersifat historis, pengukurannya dulakukan setelah kegiatannya terjadi.

\subsection{Pengertian Aktiva Tetap}

Aktiva mempunyai peranan penting dalam keberhasilan suatu perusahaan. Peranan penting aktiva tetap bagi perusahaan dapat dilihat dari jumlah relatif suatu komponen aktiva tetap itu berbeda dari perusahaan yang satu dengan perusahaan yang lainnya, tergantung dari sifat, jenis dan macam usahanya. Suatu aktiva tetap perlu adanya pengelolaan dan perlakuan akuntansi yang tepat sesuai dengan prisip akuntansi yang berlaku umum dan diterapkan secara konsisten.

Di lain pihak suatu perusahaan juga harus menerapkan peraturan perpajakan di dalam menjalankan kegiatan perusahaannya, tak terkecuali untuk aktiva tetap. Aktiva tetap merupakan aktiva berwujud yang mempunyai masa masa manfaat yang relatif lama dan dipakai atau digunakan dalam operasi normal perusahaan serta tidak dimkasudkan untuk dijual kembali, yang diperoleh dalam 
bentuk siap pakai atau dibangun lebih dahulu. Nilai yang besar dapat mempengaruhi posisi kekayaan dalam perusahaan.

Menurut Warren, Reeve and Fess (2006; 504) dalam bukunya yang berjudul "Pengantar Akuntansi" yang diterjemahkan oleh Aria Farahmita, Amunugrahani dan Taufik Hendrawan, menyatakan aktiva tetap merupakan aktiva jangka panjang atau yang relatif permanen. Mereka merupakan aktiva berwujud (tangible assets) karena terlihat secara fisik. Aktiva tersebut dimiliki dan digunakan oleh perusahaan serta tidak dimaksudkan untuk dijual sebagai bagian dari operasi normal.

Menurut Zaki Baridwan $(2004 ; 271)$ aktiva tetap berwujud adalah aktiva aktiva yang berwujud yang sifatnya relatif permanen yang digunakan dalam kegiatan perusahaan normal.

Menurut Mulyadi $(2001 ; 591)$ aktiva tetap adalah kekayaan yang memiliki wujud, mempunyai manfaat ekonomis lebih dari satu tahun, dan diperoleh perusahaan untuk melaksanakan kegiatan perusahaan, bukan untuk dijual kembali.

Ikatan Akuntansi Indonesia (2009;16.2), memberikan defenisi aktiva tetap sebagai berikut : aset tetap adalah aset berwujud yang dimiliki untuk digunakan dalam produksi atau penyediaan barang atau jasa, untuk direntalkan kepada pihak lain, atau untuk tujuan administratif dan diharapkan untuk digunakan selama lebih dari satu periode.

Berdasarkan definisi - definisi yang dikemukakan diatas, maka dapat disimpulkan bahwa aktiva tetap adalah semua aktiva berbentuk fisik yang dimiliki dan digunakan dalam operasi normal perusahaan, yang diperoleh dalam bentuk siap pakai atau dengan dibangun lebih dahulu, serta mempunyai masa manfaat lebih dari satu periode akuntansi (satu tahun) dan tidak dimaksudkan untuk dijual kembali.

3.4 Klasifikasi Aktiva Tetap

Aktiva tetap memiliki beragam jenis, bentuk dan umur manfaat, ada aktiva tetap yang umurnya tidak terbatas serta ada aktiva tetap yang umurnya terbatas. Aktiva tetap yang umurnya terbatas seperti kendaraan, sedangkan aktiva tetap yang umurnya tidak terbatas adalah tanah. Menurut Mulyadi (2001;155) mengemukakan jenis-jenis aktiva tetap terdiri dari :

1. Tanah

Seperti tanah yang digunkan sebagai tempat berdirinya gedung - gedung perusahaan.

2. Perbaikan Tanah

Seperti jalan - jalan disekitar lokasi perusahaan yang dibangun perusahaan tempat parkir, pagar, dan saluran air bawah tanah.

3. Gedung

Seperti gedung yang digunakan untuk kantor, took, pabrik, dan gudang.

4. Peralatan

Seperti peralatan kantor, peralatan pabrik, mesin - mesin, kendaraan dan mebel. Sebagaimana hal pembelian terhadap peralatan yang dilakukan, pemilihan aktiva tetap juga merupakan keputusan yang penting bagi perusahaan untuk :

a. Menjaga aktiva agar selalu dalam kondisi baik 
b. Menggantikan fasilitas yang sudah rusak

c. Menambah aktiva jika diperlukan

Menurut Syofyan Harahap (2002;23) menyatakan bahwa pada dasarnya aktiva tetap terdiri dari :

1. Tanah atau Lahan

Bidang tanah terhampar baik yang merupakan tempat bangunan maupun yang masih kosong. Dalam akuntansi, apabila ada lahan atau tanah yang didirikan bangunan diatasnya harus dipisahkan pencatatannya dari lahan itu sendiri.

2. Bangunan Gedung

Gedung merupakan bangunan yang terdiri atas bumi ini baik diatas lahan atau air, pencatatannya harus terpisah dari lahan yang menjadi lokasi gedung.

3. Mesin

Termasuk peralatan - peralatan yang menjadi bagian dari perusahaan yang bersangkutan.

4. Kendaraan

Semua jenis kendaraan seperti : alat pengangkutan, truck, traktor, forklift, mobil, kendaraan, roda dua, dll.

5. Perabot

Dalam jenis ini termasuk perabot kantor, perabot laboratorium, perabot pabrik yang merupakan isi dari suatu bangunan.

6. Inventaris atau Peralatan

Peralatan yang dianggap merupakan alat - alat besar yang dipergunakan dalam perusahaan seperti inventaris kantor, inventaris pabrik, inventaris laboratorium, inventaris gudang, dll.

7. Prasarana

Di Indonesia adalah merupakan kebiasaan bahwa perusahaan membuat klasifikasi khusus prasarana seperti jalan, jembatan, pagar dan lain - lain.

\subsection{Cara Perolehan dan Penilaian Aktiva Tetap}

Aktiva tetap dapat diperoleh dengan berbagai cara, dimana masing masing cara perolehan akan mempengaruhi penentuan harga perolehan, menurut Zaki Baridwan $(2004 ; 228)$ cara - cara perolehan aktiva tetap adalah sebagai berikut :

1. Pembelian Tunai

Aktiva berwujud yang diperoleh dari pembelian tunai dicatat dalam buku - buku dengan jumlah sebesar uang yang dikeluarkan. Dalam jumlah uang yang dikeluarkan untuk memperoleh aktiva tetap termasuk harga faktur dan semua biaya yang dikeluarkan agar semua aktiva tetap tersebut siap untuk dipakai, seperti biaya angkut, premi asuransi dalam perjalanan, biaya balik nama, biaya pemasangan dan biaya percobaan. Semua biaya - biaya diatas dikapitalisasi sebagai harga perolehan aktiva tetap.

2. Pembelian Angsuran

Apabila aktiva tetap diperoleh dari pembelian angsuran, maka dalam perolehan aktiva tetap tidak termasuk bunga. Bunga selama masa 
angsuran baik jelas - jelas dinyatakan maupun yang tidak dinyatakan sendiri, harus dikeluarkan dari harga perolehan dan dibebankan sebagai biaya bunga.

3. Penukaran Dengan Surat - Surat Berharga

Aktiva tetap diperoleh dengan cara ditukar dengan saham atau obligasi perusahaan, dicatat dalam buku sebesar harga pasar saham atau obligasi yang digunakan sebagai penukar. Pertukaran aktiva tetap dengan saham atau obligasi perusahaan akan dicatat dalam rekening modal saham atau utang obligasi sebesar nilai nominalnya, selisih nilai pertukaran dengan nilai nominal dicatat dalam rekening agio atau disagio.

4. Penukaran dengan aktiva tetap yang lain

Pembelian aktiva tetap dilakukan dengan cara tukar menukar atau tukar tambah, dimana aktiva lama dugunakan untuk membayar harga aktiva baru baik seluruhnya atau sebahagian dimana kekurangannya dibayar tunai. Dalam prinsip ini harga perolehan aktiva tetap harus digunakan yaitu aktiva baru dikapitalisasikan dengan jumlah sebesar harga pasar aktiva lama ditambah uang yang dibayarkan atau dikapitalisasikan sebesar harga pasar aktiva baru yang diterima. Masalah yang timbul bila harga pasar aktiva lama maupun baru tidak dapat ditentukan, dalam hal ini nilai buku yang lama akan digunakan sebagai dasar pencatatan pertukaran tersebut mengenai masalah rugi atau laba pertukaran dipisahkan menjadi dua yaitu :

5. Pertukaran aktiva tetap yang tidak sejenis

Yang dimaksud dengan pertukaran aktiva tetap tidak sejenis adalah pertukaran aktiva tetap yang sifat dan fungsinya tidak sama seperti pertukaran tanah dengan mesin - mesin tanah dengan gedung dan lain lain. Dalam prinsip akuntansi dinyatakan bahwa bila menyangkut pertukaran dengan aktiva yang tidak sejenis perbedaan antara nilai buku aktiva tetap yang diserahkan dengan nilai wajar yang digunakan sebagai dasar pencatatan aktiva yang diperoleh pada tanggal transaksi terjadi harus diakui sebagai laba atau rugi pertukaran aktiva tetap.

6. Pertukaran aktiva tetap yang sejenis

Dalam hubungan dengan aktiva tetap yang sejenis prinsip akuntansi Indonesia menyatakan bahwa laba yang timbul akan ditangguhkan (mengurangi harga perolehan aktiva yang bersangkutan) dalam hal pertukaran aktiva yang sejenis.

7. Diperoleh dari hadiah atau donasi

Aktiva tetap yang diperoleh dari hadiah atau donasi, pencatatannya biasa dilakukan menyimpang dari prinsip harga perolehan. Untuk menerima hadiah mungkin dikeluarkan biaya - biaya tetapi biaya - biaya tersebut jauh lebih kecil dari nilai aktiva tetap yang diterima.

3.6 Biaya - Biaya Selama Masa Penggunaan Aktiva Tetap

Aktiva tetap yang dimiliki dan digunakan dalam usaha perusahaan akan memerlukan pengeluaran - pengeluaran yang tujuannya adalah agar dapat memenuhi kebutuhan perusahaan. 
Menurut Zaki Baridwan (2004;289), pengeluaran - pengeluaran tersebut dapat dikelompokkan menjadi :

1. Reparasi dan pemeliharaan

Biaya reparasi dapat merupakan biaya yang jumlahnya kecil jika reparasinya biasa, dan jumlahnya cukup besar jika reparasinya besar. Biaya reparasi kecil seperti penggantian baut, mor, skring mesin merupakan biaya yang sering terjadi. Karena biaya reparasi dan pemeliharaan sering terjadi maka dapat disimpulkan bahwa manfaat biaya - biaya tersebut hanya dalam periode terjadinya. Sehingga dicatat sebagai biaya (pengeluaran pendapatan).

2. Penggantian

Penggantian adalah biaya yang dikeluarkan untuk menggantikan aktiva atau bagian aktiva dengan unit yang baru dan tipe yang sama, misalnya penggantian dinamo mesin. Biasanya penggantian ini terjadi karena aktiva lama sudah tidak berfungsi lagi atau rusak.

3. Perbaikan (Improvement)

Yang dimaksudkan dengan perbaikan adalah penggantian suatu aktiva dengan aktiva baru untuk memperoleh yang lebih besar. Perbaikan yang biasanya kecil dapat dilakukan reparasi biaya, tetapi reparasi yang memakan biaya yang besar dicatat sebagai aktiva baru.

4. Penambahan (Addition)

Penambahan adalah memperbesar atau memperluas fasilitas suatu aktiva seperti penambahan ruang dalam bangungan, ruang parkir dan lain - lain.

5. Penyusunan kembali aktiva tetap

Biaya yang dikeluarkan dalam penyusunan kembali aktiva atau untuk mengurangi biaya - biaya produksi, jika jumlahnya cukup berarti dan manfaat penyusunan kembali akan dirasakan lebih dari satu periode akuntansi maka dikapitalisasi.

3.7 Depresiasi Terhadap Aktiva Tetap

Penyusutan (depresiasi) adalah sebagian dari harga perolehan aktiva tetap yang secara sistematis dialokasikan menjadi beban pada setiap periode Akuntansi Selama Umur Ekonomis Aktiva Tetap.

Ikatan Akuntansi Indonesia (2009;16-8), mendefenisikan penyusutan adalah entitas mengalokasikan jumlah pengakuan awal aset pada bagian aset tetap yang signifikan dan menyusutkan secara terpisah setiap bagian tersebut.

Menurut Zaki Baridwan (2004;305) depresiasi adalah sebagian dari harga perolehan aktiva tetap yang secara sistematis dialokasikan menjadi biaya setiap periode akuntansi.

Ada beberapa metode yang dapat digunakan untuk menghitung beban depresiasi periodik. Untuk dapat memilih salah satu metode hendaknya dipertimbangkan keadaan - keadaan yang mempengaruhi aktiva tersebut menurut Zaki Baridwan (2004) metode - metode tersebut adalah :

1. Metode garis lurus (straight-line method)

Metode ini adalah metode depresiasi yang paling sederhana dan banyak digunakan. Dalam cara ini beban depresiasi tiap periode jumlahnya sama ( kecuali kalau ada penyesuaian - penyesuaian ) 


$$
\text { Depresiasi }=\frac{\mathrm{HP}-\mathrm{NS}}{\mathrm{n}}
$$

Keterangan :

HP = Harga Perolehan

NS = Nilai Sisa ( Residu )

$\mathrm{n} \quad=$ Taksiran Umur Kegunaan ( Umur Ekonomis )

2. Metode jam jasa ( service-hours method)

Metode didasarkan pada anggapan bahwa aktiva (terutama mesin mesin) akan lebih cepat rusak bila digunakan sepenuhnya (full time) dibanding dengan penggunaan yang tidak sepenuhnya (part time). Dalam cara ini beban depresiasi dihitung dengan satuan jam jasa. Beban depresiasi periodik besar akan sangat tergantung pada jam jasa yang terpakai ( digunakan ).

$$
\text { Depresiasi per jam }=\frac{\mathrm{HP}-\mathrm{NS}}{\mathrm{n}}
$$

Keterangan :

$\mathrm{HP}=$ Harga Perolehan

NS = Nilai Sisa

$\mathrm{n} \quad=$ Taksiran Jam Jasa

3. Metode hasil produksi ( productive-output method)

Dalam metode ini umur kegunaan aktiva ditaksir dalam satuan jumlah unit hasil produksi. Beban depresiasi dihitung dengan dasar satuan hasil produksi, sehingga depresiasi tiap periode akan berfluktuasi sesuai dengan fluktuasi dalam hasil produksi. Dasar teori yang digunakan adalah bahwa suatu aktiva itu dimiliki untuk menghasilkan produk, sehingga penyusutan juga didasarkan pada jumlah produk yang dapat dihasilkan.

$$
\text { Depresiasi / unit }=\frac{\mathrm{HP}-\mathrm{NS}}{\mathrm{n}}
$$

Keterangan :

HP = Harga Produksi

NS = Nilai Sisa

$\mathrm{n} \quad=$ Taksiran Hasil Produksi ( unit)

4. Metode beban berkurang ( reducing-charge method)

Dalam metode ini beban depresiasi tahun - tahun pertama akan lebih besar dari pada beban depresiasi tahun - tahun berikutnya. Metode ini didasarkan pada teori bahwa aktiva yang baru akan dapat digunakan lebih efisien dibandingkan dengan aktiva yang lebih tua. Biasanya aktiva yang baru akan memerlukan reparasi dan pemeliharaan yang lebih sedikit dibandingkan dengan aktiva yang lama.

Ada empat cara untuk menghitung beban depresiasi yang menurun dari tahun ke tahun yaitu :

a. Jumlah angka tahun ( sum of years-digits method) 
Di dalam metode ini depresiasi dihitung dengan cara mengalihkan bagian pengurangan ( reducing fractions ) yang setiap tahunnya selalu menurun dengan harga perolehan dikurangi nilai residu. Bagian pengurang ini dihitung sebagai berikut :

Pembilang = bobot untuk tahun yang bersangkutan.

Penyebut = jumlah angka tahun selama umur ekonomis aktiva tetap atau jumlah angka bobot.

b. Saldo menurun (Declening balance method)

Dalam cara ini beban depresiasi periodik dihitung dengan cara mengalihkan tarif yang tetap dengan nilai buku aktiva. Karena nilai buku aktiva ini setiap tahun selalu menurun maka beban depresiasi setiap tahunnya juga selalu menurun. Tarif ini dihitung dengan menggunakan rumus sebagai berikut :

$$
T=1-\sqrt[n]{\frac{N S}{H P}}
$$

$$
\begin{array}{ll}
\mathrm{T} & =\text { Tarif } \\
\mathrm{n} & =\text { Umur Ekonomis } \\
\mathrm{NS} & =\text { Nilai Sisa } \\
\mathrm{HP} & =\text { Harga Perolehan }
\end{array}
$$

c. Double Declining Balance Method

Dalam metode ini beban depresiasi setiap tahunnya menurun untuk dapat menghitung beban depresiasi yang selalu menurun, dasar yang digunakan adalah persentase depresiasi dengan cara garis lurus. Persentase ini dikalikan dua dan setiap tahunnya dikalikan pada nilai buku aktiva tetap. Karena nilai buku selalu menurun maka beban penyusutan juga selalu menurun.

d. Tarif Menurun (Declining rate on cost method)

Disamping metode - metode yang telah diuraikan di atas, kadang kadang dijumpai cara menghitung penyusunan dengan menggunakan tarif (\%) yang selalu menurun. Tarif (\%) ini setiap periode dikalikan dengan harga perolehan. Penurunan tarif (\%) setiap periode dilakukan tanpa menggunakan dasar yang pasti, tetapi digunakan berdasarkan kebijaksanaan pimpinan perusahaan. Karena tarif (\%) setiap periode selalu menurun, maka beban depresiasinya juga selalu menurun.

\subsection{Deplesi}

Menurut Zaki Baridwan ( 2004;321), Deplesi adalah berkurangnya harga perolehan (cost) atau nilai - nilai sumber alam seperti tambang dan hutan kayu yang disebabkan oleh perubahan ( pengolahan ) sumber - sumber alam tersebut. Metode perhitungan deplesi :

1. Harga perolehan aktiva

2. Taksiran nilai sisa apabila sumber alam sudah selesai dieksploitasi

3. Taksiran hasil yang secara ekonomis dapat dieksploitasi

\subsection{Penghentian Aktiva Tetap}


Aktiva tetap yang dipergunakan oleh perusahaan mempunyai umur ekonomis yang beragam dan sangat terbatas. Hal ini disebabkan oleh perkembangan teknologi atau memang aktiva tersebut sudah tidak dapat lagi mendatangkan manfaat bagi perusahaan, sehingga penggunaan aktiva tetap dapat dihentikan.

Menurut Zaki Baridwan (2004;293) aktiva tetap dapat dihentikan dengan cara dijual, ditukarkan, ataupun karena rusak. Pada waktu aktiva tetap dihentikan dari pemakaian maka semua memang yang berhubungan dengan aktiva tetap tersebut dihapus.

Penghentian pemakaian aktiva tetap :

1. Habis umur ekonomis

2. Sebelum habis umur ekonomis

Apabila suatu aktiva tetap dihentikan dari pemakaian sebelum aktiva tersebut didepresiasi penuh dan aktiva bekas tersebut tidak laku dijual, maka perusahaan akan mengalami kerugian.

3.10. Perencanaan Aktiva Tetap

Pada dasarnya, tidak satupun perusahaan bermaksud dan merencanakan untuk menjual aktiva tetapnya, karena aktiva tetap dibeli dimaksudkan untuk dipergunakan selama umur ekonomisnya untuk menjaga kelangsungan usaha (entah untuk berproduksi, dijadikan tempat usaha, dijadikan peralatan kerja, dan lain sebagainya).

Adapun tujuan dari perencanaan aktiva tetap adalah :

1. Menetapkan tingkat pembelian yang mungkin diperoleh atas investasi aktiva tetap yang direncanakan.

2. Menseleksi proyek - proyek yang memberikan pengembalian yang relatif besar atas investasi.

3. Menetapkan bahwa seluruh pengeluaran untuk barang modal yang direncanakan berada dalam batas - batas kemampuan keuangan perusahaan.

4. Menetapkan bahwa program jangka pendek aktiva tetap adalah sesuai dengan rencana jangka panjang perusahaan.

5. Menetapkan waktu yang tepat untuk melakukan pengeluaran modal.

3.11 Pengendalian Aktiva Tetap

Prosedur pengelolaan aktiva tetap tersebut dimulai dari tahap perencanaan pengadaan aktiva tetap dan diakhiri pada kegiatan pencatatan, yaitu meliputi prosedur pengadaan barang inventaris, prosedur reparasi dan pemeliharaan, prosedur penghentian/penghapusan aktiva tetap, prosedur penyusutan, prosedur revaluasi.

Prosedur pengelolaan aktiva tetap ini dilakukan karena aktiva tetap mempunyai karakteristik yang berlainan dengan aktiva lancar. Jika aktiva lancar dikendalikan pada saat konsumsinya, sedangkan pengendalian aktiva tetap dilaksanakan pada saat perencanaan perolehan atau pengadaan aktiva tetap tersebut.

Hal ini disebabkan karena banyak pengeluaran - pengeluaran yang bersangkutan dengan aktiva tetap yang tidak dapat dihindarkan karena berupa committed cost yang dalam masa pengoperasian aktiva tetap sejenis biaya tersebut 
tidak dapat dikendalikan oleh manajemen melalui wewenang yang dimilikinya, sehingga prosedur atau sistem pengelolaan aktiva tetap yang dibuat, bermula dari pengadaan aktiva tetap.

IV. Penutup

Dana yang ditanamkan dalam aktiva tetap seperti halnya dana yang ditanamkan dalam aktiva lancar juga mengalami proses perputaran. Secara konsepsionil sebenarnya tidak ada perbedaannya investasi dalam aktiva lancar dengan aktiva tetap. Perusahaan menanamkan dana dalam aktiva lancar dengan harapan bahwa perusahaan akan dapat memperoleh kembali dana yang telah diinvestasikan dalam aktiva lancar tersebut. Demikian juga dengan investasi pada aktiva tetap, perusahaaan juga mengharapkan akan mendapatkan kembali dana yang telah diinvestasi tersebut. Perbedaan antara keduanya adalah, investasi dalam aktiva lancar diharapkan akn diterima kembali dalam jangja waktu pendek sedangkan investasi dalam aktiva tetap membutuhkan jangka waktu pengembalian yang lama. Oleeh sebab itu setiap perusahaan perlu untuk membuat perencanaan dan pengendalian terhadap aktiva tetapnya.

\section{Daftar Pustaka}

Baridwan, Zaky, 2004, Intermediate Accounting, Edisi Kedelapan, Cetakan Pertama, BPFE, Yogyakarta.

Dr. Nur Indriantono, M. Sc. Akuntan dan Drs. Bambang Supomo, M. Si. Akuntan, 2009, Metodologi Penelitian Bisnis, Edisi Pertama, Cetakan Ketiga, BPFE, Yogyakarta.

Ernawati, Neng, 2007, “Analisa Penerapan Akuntansi Penyusutan Aktiva Tetap Berwujud Menurut PSAK No. 17 Pada PT. P Nusantara V Unit PPKR Bukit Selasih", Universitas Putra Indonesia "YPTK", Padang.

Handoko, Hani, 2001, Manajemen Personalia dan SDM, Penerbit BPFE, Yogyakarta.

Hansen, Don R dan Maryanne M Mowen, 2000. Akuntansi Manajemen, Terjemahan Ancella. A. Hermawan, Buku Satu, Edisi Keempat, Salemba Empat, Jakarta.

Harahap, Sofyan Syafri, 2002, Teori Akuntansi, Cetakan Ketiga, Penerbit PT. Raja Grafindo, Jakarta.

Hasibuan, Malayu S.P., 2001, Manajemen Sumber Daya Manusia, Jakarta: Bumi Aksara.

Ikatan Akuntan Indonesia, 2009, Standar Akuntansi Keuangan, Penerbit Salemba Empat, Jakarta.

M. Nasir, 2003, "Perlakuan Akuntansi Aktiva Tetap Studi Kasus Pada PT. (Persero) Pelabuhan Indonesia II Cabang Teluk Bayur”, Universitas Putra Indonesia "YPTK", Padang.

Mulyadi, 2001, Sistem Akuntansi, Edisi 1, Cetakan Tiga, Penerbit: Salemba Empat, Jakarta. 
Narafin M, 2004 Penganggaran Perusahaan, Edisi Revisi, Jakarta: Salemba Empat.

Putri, Guspita Yulida, 2004, “Perlakuan Akuntansi Terhadap Aktiva Tetap Bangunan Dan Kendaraan Yang Dimiliki Oleh PT. United Tractors Tbk Cabang Padang”, Universitas Putra Indonesia "YPTK", Padang.

Warren, Reeve, Fess, 2006, Pengantar Akuntansi, Buku Satu, Edisi ke 21, diterjemahkan oleh Aria Farahmita, Amanugrahani, Taufik Hendrawan, Penerbit: Salemba Empat, Jakarta.

Welsch, Hilton, Gordon, 2000. Anggaran: Perencanaan dan Pengendalian Laba, Terjemahan Purwatiningsih dan Maudy Warouw, Edisi Pertama, Salemba Empat, Jakarta. 